\title{
Post-Viral Olfactory Loss: A Survey of One Hundred and Twenty Patient Experiences
}

\author{
Carl Philpott ${ }^{1}$, James Boardman ${ }^{2}$, and Duncan Boak ${ }^{2}$ \\ ${ }^{1}$ University of East Anglia \\ ${ }^{2}$ Fifth Sense
}

April 28, 2020

\begin{abstract}
1. The age range of patients responding to the survey was $28-85$ with a mean of $58 \pm 12$ years with the duration of their disorder less than 5 years in $63 \%$ of cases.

2. Patients experience variable treatment, if at all, for post-viral olfactory loss

3. If treatment is given oral and/or intranasal steroids are typically given.

4. Several patients reported receiving imaging despite this not being clinically useful when there is a clear history and normal examination.

5. Over two thirds of patients experience parosmia and up to 5 years of the onset of the problem were still actively seeking a solution.
\end{abstract}

\section{Hosted file}

Suffering With PVOL- Fifth Sense Members' Survey Paper 1.1.docx available at https://authorea. com/users/314083/articles/446288-post-viral-olfactory-loss-a-survey-of-one-hundred-and-twentypatient-experiences 